\title{
What's in a Name? Causes and Consequences of Labelling Minorities as "National" or "Migrant": Roma in Italy and Spain
}

\author{
Tina Magazzini* (D)
}

\begin{abstract}
This article analyses how Roma are represented in official policy narratives in Italy and Spain by comparing the four cycles of the Framework Convention for the Protection of National Minorities in the two countries. By tracing the representations that the Italian and Spanish governments hold (and make) about the Roma, I sketch out the different categories that EUropean countries recur to as organizing principles to "other" underprivileged minorities. Based on the tailored-approaches in which both Italy and Spain engage in framing Roma as either a "national" minority or not, I suggest that constructing or "producing" a minority in our imagined communities as characterized by national, cultural, social or migrant characteristics relies more on political expediency than on objective analytical categories.
\end{abstract}

\section{INTRODUCTION}

"When I use a word", Humpty Dumpty said, in a rather scornful tone,

"it means just what I choose it to mean - neither more nor less."

"The question is," said Alice,

"whether you can make words mean so many different things."

"The question is," said Humpty Dumpty,

"which is to be master - that's all."

(Lewis Carroll, Through The Looking Glass)

Social cohesion, migrant integration and Roma inclusion feature prominently in national and European research and policy agendas, and represent one of the most pressing priorities identified by European institutions (Council of Europe, 2016c, 2016d, European Commission, 2015, 2016). Within the far-ranging debates on migration and integration, "Roma integration" has become a field in its own right, ${ }^{1}$ yet one that has traditionally been addressed in isolation from the wider dynamics of migration and integration regimes, growing inequalities and minority governance.

Recent scholarship has started to recognize the need to overcome such "splendid isolation" (Willems, 1997, pp. 305-306), acknowledging that the framing of the Roma as a minority "in need of integration" is relevant not only for minority protection but also for issues revolving around European citizenship, the surge in populist xenophobic parties and the so-called "migrant crisis"2 (Kostka, 2015; Sardelić, 2016; Sigona \& Treheran, 2009; Vermeersch, 2013; Yıldız \& Genova, 2017).

The relevance of Roma political and legal classifiers for the study of migration in Europe is, in my opinion, two-fold: on the one hand, Roma integration policies are by and large a product of the

* University of Deusto, Faculty of Social and Human Sciences 
EU freedom of movement. On the other hand, the recent influx of refugees in Europe has rekindled what has been called "the last acceptable form of racism", Romanophobia (McGarry, 2017).

Regarding the claim that freedom of movement is at the root of Roma-targeted policies, a European Commission desk officer and member of the EU Roma Task Force commented on the creation of the EU Roma Integration Strategy: "The tension was already high with Italy and Maroni ${ }^{3}$ even before the French evictions and repatriations [of Romanian Roma] of 2010. ${ }^{4}$ As to the 2004 enlargement countries, they didn"t even want to see the problem: as a matter of fact, they actually preferred for the Roma to migrate westwards." (Email exchange, my translation from Italian, 17 April 2017).

In other words, by 2010 the ongoing so-called "nomad emergency" decrees adopted by Italy and the repatriations of Romanian Roma carried out by France had pushed the issue of Roma integration high on the European agenda, more than any poverty level or discrimination suffered by Roma individuals or communities could have done.

Regarding the assertion that the so-called "migration crisis" has repercussions on the attitudes of mainstream media and politicians towards Roma minorities, as Sardelić and McGarry pointed out:

Time and again, Romani communities have been drawn into national asylum policy debates raising issues of inclusion, integration and belonging. [...] In fact, the failure of different states to integrate Roma has been used as a justification to exclude other asylum seekers.

(Sardelić \& McGarry, 2017)

The present article aims to contribute to the abovementioned strand of research, which is situated at the intersection of public policy, migration, citizenship and Romani studies. I do so by analyzing the representation that the governments of Italy and Spain hold (and make) about the Roma as either "foreigners/ migrants" or "nationals".

In the first section, I situate the theoretical debate on framing the Roma and in the second section I justify the choice of a comparative analysis between Italy and Spain. The third section analyses how the representations of the Roma as a minority(ies) have developed and evolved in the two countries over the years. In the fourth section I situate these representations within the wider context of the politics of identity in contemporary Europe, and finally I draw some conclusions on why the same ethnic minority in two relatively similar countries is constructed in such different ways.

What emerges from an analysis of the legal frameworks adopted by Italy and Spain with respect to Roma minorities is that both governments need to address two audiences -their own national polity and European institutions. For this reason, the interpretation they make regarding "what kind of minority" the Roma constitute in official policies are ridden with incoherencies that stem from trying to use the European institutions' vocabulary in ways that fit with, and bend to, national purposes.

\section{THE FRAMING OF ROMA IDENTITY AND CLASSIFIERS IN EUROPE}

In his 2016 book Those Who Count: Expert Practices of Roma Classification, Mihai Surdu makes a convincing case that, rather than studying Romani culture, language or traditions, the most effective way to make sense of the current socio-political standing of the Roma in Europe - and of what Yildiz and De Genova call "their production (and reproduction) as a distinctly racialized "group"” (Yıldız \& Genova, 2017) - is a study of the ways in which policymakers classify Roma people.

The discourse on Roma identity, which spills over into the more recent Roma integration debate, has been traditionally divided in two main strands: the Romani studies literature has conceptualized 
Roma minorities either in terms of ethno-cultural diversity from the majority population or of socio-economic marginalization (Yıldız \& Genova, 2017).

The two cases analysed in this article sit at the two opposite poles of this spectrum: Spain has so far employed a mainly economic-centred approach towards its Roma population, while Italy has promoted a narrative of the Roma as a mainly cultural minority.

Either way, integration policies tend to be founded upon strongly loaded concepts of group differentiation between Roma and non-Roma, according to which the Roma constitute, or suffer from, some kind of "problem" (Ciaian \& Kancs, 2016; Rossi, 2016).

My opening hypothesis is that the way in which such a "problem" is understood by national authorities is profoundly consequential for the integration approaches that end up being adopted towards Roma minorities by different countries. Because policies give shape to "problems" (Bacchi, 2009) the aim here is that of understanding what kind of underlying assumptions have shaped the current Roma inclusion schemes differently in Italy and Spain. I thus apply a "what is the problem represented to be?" (WPR) approach to Roma policies.

Carol Bacchi's WPR approach challenges the idea of policy-problems being apolitical, and recommends "working backwards" from the policy measures. This helps to reveal what the priorities and goals of the decision-makers are, and allows for non-preconceived categories to emerge (Bacchi, 2009, p. 3).

Using this approach, in the following sections I look at whether the matter of Roma minorities is framed by expert categorizers in Italy and Spain in terms of cultural diversity, of socio-economic disadvantage, both, neither, or other meaningful categorizations. While not included as an initial category, we will see that "migration" emerges as an important component in this debate.

\section{METHODOLOGY}

In order to locate the main frames through which Roma have been distinguished as an object of targeted policies over the years I used a hybrid process of inductive and deductive thematic analysis, meaning that I integrated theory-driven codes (the cultural frame and the economic frame) with data-driven codes to identify the main themes present in the official legislation regarding Roma in Italy and Spain. Beyond the two departing categories of cultural difference and of socio-economic marginalization, two additional frames that emerged in analyzing the documents are those of a) migratory status and of b) exceptional/ "complex issue".

What follows is a thematic analysis of Roma representation in the documents related to, and surrounding, the Spanish and Italian four cycles of the Framework Convention for the Protection of National Minorities (FCNM, 1999-2016). A detailed discourse analysis of the documents, comprising of over 1,000 pages, would not be feasible (nor do I believe it is necessary). However, by highlighting the states' view on "who" should be targeted by Roma policies, I show how the construction of the Roma as an ethnic and political category has developed differently in the two countries, thus providing different sets of "solutions" to the perceived "problem".

In the analysis of the data I pay particular attention to who is identified as a target group, and what kind of logic the policy framing of "Roma integration" responds to. For the scope of this article the 2012 National Roma Integration Strategies (NRIS) are not addressed specifically, nor are the regional laws explicitly targeted at Roma that exist in both countries. While it would be interesting to include them in a more comprehensive analysis taking into account all the legislation regarding the Roma population, I believe that the reports of the FCNM are sufficient to grasp the general trends of Roma labelling and categorization, since they offer a longitudinal look at the ways in which this minority has been officially classified since the late 1990s. 


\title{
Why Italy and Spain
}

Italy and Spain are comparable for a number of reasons that can be grouped along four axes.

Firstly, amongst Western European countries, Spain and Italy are States of recent incoming migration flows and they have reasonably similar systems in terms of State models and regional competencies. A vast literature has suggested that Italy and Spain are comparable in their experiences of immigration and welfare provision, as part of the "Southern European" or "Mediterranean" model (Aiginger \& Leoni, 2009; Arango, Finotelli, Sabino, Strozza, \& Triandafyllidou, 2009; McMahon, 2015, pp. 4-8). Both countries have a long history of emigration, and they have only over the past few decades become destination countries for migrants coming from CEE countries, North Africa and Latin America.

Secondly, in terms of governmental competencies and administrative power, both Italy and Spain are decentralized unitary states in which the regions and the autonomous communities - 20 (of which one is divided in 2 autonomous provinces) and 17 (plus 2 autonomous cities) respectively - are granted residual policy competence and where asymmetry between the regions is recognized. They both differ significantly from highly centralized States such as France, as well as from federal States such as Germany, and from partially decentralized ones such as the United Kingdom (Ruiz Vieytez, 2013, p. 86).

Thirdly, in economic terms, both Italy and Spain were hit hard by the economic crisis of 2008, and in both countries the crisis amplified some already existing trends. Both Italy and Spain had to adopt unpopular austerity measures and the economic crisis turned into a social crisis which saw the emergence of new parties. It has been written that:

\begin{abstract}
"Within the European context, Spain and Italy share many common characteristics. They share the cultural, social and political effects of economic crisis. [...] As a consequence of crisis, expenditures in welfare state are cut. The crisis amplifies uncertainties and risks typical of late-modernity and exacerbates the processes of individualization. The economic crisis turns into a political, social and cultural crisis."
\end{abstract}

(Penalva Verdú, Raffini et al., 2015, p. 18).

Fourthly, neither the Italian Republic nor the Spanish Kingdom officially recognize their own citizens of Roma ethnicity as a national minority in the same way as CEE countries do, but both countries include them in their FCNM reports and have developed a NRIS. Integration measures and policies that explicitly target Roma minorities are therefore currently in place in both countries, and while they have developed along quite different trajectories, they evolved roughly in parallel in terms of time-frame, changes in migratory flows and national responses to such changes.

\section{ROMA RECOGNITION IN THE FRAMEWORK CONVENTION FOR THE PROTECTION OF NATIONAL MINORITIES}

The Framework Convention for the Protection of National Minorities is a multilateral treaty of the Council of Europe that came into effect in 1998 as a result of increased concern about the protection of ethnic, religious and linguistic minorities, particularly "with the collapse of European communist regimes, extreme nationalism and conflicts in certain parts of Europe" (Council of Europe, 2016). It is a binding instrument under international law and it has a monitoring procedure through which reports on the situation of minorities are regularly issued by the signatory States and assessed by an Advisory Committee made up of independent experts, which advises the Committee of Ministers of the Council of Europe. The methodology of the preparation of the periodic country reports is based on the rules of procedure. ${ }^{5}$ The basic idea is that every five years each of the signatory States submits a State Report on the situation of the national minorities in their country. The 
State Report is prepared by the respective government in consultation with relevant minority organizations, sent to the FCNM Advisory Committee and published. Alternative reports on the implementation of the Framework can also be submitted, and often are, by different NGOs.

In a second stage the Advisory Committee on the Framework ${ }^{6}$ evaluates the reports and the measures taken by the governments, and requests additional information. As a part of this process, a delegation of the Advisory Committee visits the country to meet officials, ombudsmen, and human rights NGOs. Upon return from the country visit, an opinion is adopted by the Advisory Committee, which is made public and transmitted to the respective government. The government can, in a third stage, comment on the opinion. Based on these reports the Committee of Ministers of the Council of Europe $(\mathrm{CoE})$ adopts a resolution and formulates recommendations to the State party (i.e. the government). The recommendation is also published and there is a monitoring follow up phase.

In a recent thematic commentary on the scope of application of the FCNM, the Council of Europe stressed the fact that "[t]he Framework Convention addresses society as a whole and not just individuals or specific groups. Rather than asking "who" should be protected [by the FCNM], it asks "what" is required to manage diversity most effectively through the protection of minority rights." (The Council of Europe, 2016, p. 3). The State Reports, Opinions, Comments and Resolutions, however, remain largely focused on who should be protected - which minorities and groups are eligible for ad hoc measures, and according to which rationale.

Italy and Spain are both party signatories to the FCNM which, having come into effect in 1998, has now concluded its 4 th cycle. As mentioned earlier, neither Italy nor Spain officially recognize Roma as a minority in their respective national legislation, but they do systematically include the Roma in their FCNM Reports to the CoE, which amounts to a sort of informal recognition. It is therefore of interest to see how the two countries have framed the Roma discourse in their FCNM reports, and how these frames have evolved over the past two decades, as well as how the issue of "formal" invisibility in terms of legal recognition copes with "informal" (yet institutionally sanctioned) ad hoc measures, and what the policy implications are. For issues of length constraints, this section focuses mainly on the state reports, but the opinions, comments and resolutions are also mentioned in cases of particular relevance.

Table 1 represents the timeline of the FCNM cycles for Italy and Spain.

\section{First Cycle}

\section{Italy}

Starting from the first cycle of the country-specific monitoring of the FCNM, it is clear that Italy and Spain chose to give a different meaning to the terms "national minorities" and to "Roma".

TABLE 1

TIMELINE OF THE 4 CYCLES OF THE FCNM FOR ITALY AND SPAIN

\begin{tabular}{|l|llll|}
\hline Cycle & State Report & Opinion & Comments & Resolution \\
\hline $1^{\text {st }}$ Italy & 3 May 1999 & 14 Sep 2001 & 31 Jan 2002 & 3 Jul 2002 \\
$1^{\text {st }}$ Spain & 19 Dec 2000 & 27 Nov 2003 & 10 Jun 2004 & 30 Sep 2004 \\
$2^{\text {nd }}$ Italy & 14 May 2004 & 24 Feb 2005 & 4 Oct 2005 & 14 Jun 2006 \\
$2^{\text {nd }}$ Spain & 10 Apr 2006 & 22 Feb 2007 & 11 Dec 2007 & 2 Apr 2008 \\
$3^{\text {rd }}$ Italy & 21 Dec 2009 & 15 Oct 2010 & 20 May 2011 & 4 Jul 2012 \\
$3^{\text {rd }}$ Spain & 23 Aug 2010 & 22 Mar 2012 & 13 Nov 2012 & 10 Jul 2013 \\
$4^{\text {th }}$ Italy & 12 Mar 2014 & 19 Nov 2015 & 12 Jul 2016 & 5 Jul 2017 \\
$4^{\text {th }}$ Spain & 4 Mar 2014 & 3 Dec 2014 & 12 Jun 2015 & 6 Jul 2016 \\
\hline
\end{tabular}


In its first report, Italy associated "national minorities" only and exclusively with linguistic minorities: "For historical reasons Italy has a multilingual context, with different populations which have been settled in its territory for centuries; it includes communities whose languages are German, Albanian, Greek, Slovenian and Croat, Franco-Provençal, French, Occitan, Ladin, Sardinian and Friulan" (Italian Government, 1999a, p. 3). The same report also recalled article 6 of the Italian Constitution, which states that "The Republic shall safeguard linguistic minorities by means of special provisions". Indeed, in accordance with this principle, a few months after submitting the first report Italy passed a law (482/1999) for the protection of the so-called "Historic Linguistic Minorities" that aimed at safeguarding "the languages and culture of the Albanians, Catalans, Germans, Greeks, Slovenians and Croatians, as well as of those speaking French, Friulan, Ladin, Occitan and Sardinian" (Italian Government, 1999b). The law established a national fund for the protection of linguistic minorities in order to ensure the teaching of the minority languages and cultural traditions, and for their use in official acts at various administrative levels, as well as in the media (Council of Europe, 2016a; Italian Government, 1999a, p. 31). The absence of Romanés as a recognized minority language in this setting is telling. According to a draft of law 482 based on the First report on the status of minorities in Italy of 1994, Roma and Sinti were considered a minority ${ }^{7}$, but in the final stages of the law approval they were eventually excluded from the scope of the law because of the resistance of a significant section of the Parliament, which argued that Roma and Sinti failed the "territoriality" criterion required by the State for the protection of minorities (Tavani, 2012, pp. 209-211). The reference to the Roma minority in Italy's first FCNM report (under the label "gypsies") was therefore limited to the sentence "A number of regional laws specifically intended to protect gypsies have also been adopted. In addition, a number of Bills on the protection of gypsies are currently being examined by Parliament." (Italian Government, 1999a, p. 16). At table 18 an estimate of 130.000 "gypsies" was included as a "minority with no connection with any particular territory"8 (Italian Government, 1999a, p. 34).

In response to the Advisory Committee's concern for the denigratory term "gypsy" ("zingaro" in Italian) used in the report, Italy's government took note in 2002 "of the advisability of identifying the gypsy minority more correctly using the terms 'Roma, Sinti and Travellers', which will be used henceforth" (Italian Government, 2002, p. 4). At the same time, however, it made clear that "On the subject of the Roma minorities, the understanding is that this minority does not fall within the scope of protection provided by Law No 482/1999." It is noteworthy that, in supporting this stance, the Italian government claimed that the purpose for neither recognizing nor promoting the Romani language was "to enable these individuals to become more easily incorporated into Italy, linguistically and culturally, for which it has been decided to give preference to focusing on the learning of the Italian language, also considering the difficulty of finding any Roma or Sinti language teachers." Above and beyond the fact that the numbers of Romanés speakers in Italy exceed those of some of the communities whose minority languages are included in and protected by Law 482/1999, the above mentioned passage gives us important information on the Italian approach at the time: firstly, the Roma minority was seen as an "external" body to be "incorporated into Italy" by means of linguistic and cultural assimilation (despite the majority of Roma in Italy in the late 90 s and early 2000 s being Italian citizens for generations). Secondly, the difficulties in said "incorporation" were identified in "the enormous economic, social and also psychological obstacles they face" (Italian Government, 2002, p. 6). The target group seems thus to be identified with the Romani groups that migrated from Yugoslavia following the collapse of Eastern European State Socialism, yet no real policies were envisioned in order to reduce such obstacles.

\section{Spain}

The first report of the Spanish state to the Council of Europe presents a very different picture. Nowhere in the report is the expression "national minorities" to be found other than in the title of 
the document, and much less defined: the Roma minority (identified as "Spanish Roma Community") is, as a matter of fact, the only one included.

The report's introduction opening statement is that "Spain offers an example of coexistence because it has, throughout its history, been influenced by the cultures and life-styles of many different peoples and population groups" (Spanish Government, 2000, p. 3) and at page 4 it says that "all the surveys show that the Roma are the most unpopular of the minority groups". Yet nowhere does the report say what other minority groups exist in Spain.

The introduction is followed by an "Information on the Spanish Roma Community" section that comprises a summary of the Roma's "Social and demographic situation", in which it emerges that the estimated 600,000-650,000 Spanish Roma are overrepresented in early-school dropout, health problems, and low life-expectancy. ${ }^{9}$

In terms of cultural diversity recognition and management, it is noted on page 3 that "the Spanish Roma population does not constitute a 'whole', but comprises various communities - although all of them have preserved the same basic identity, culture, value system, social organization and language (mostly based on the caló dialect)." 10 The elements of the "basic identity, culture and value system" of the Spanish Roma are identified in the report as the family being the basic social unit; a history of discrimination and unequal treatment; and the Romani language (Spanish Government, 2000, p. 4). It should however be noted that the scope of the application of the 1992 European Charter for Regional or Minority Languages (ECML) Spain (that, differently from Italy, ratified the Charter in 2001) includes Aragonese, Aranese, Asturian, Basque, Catalan, Galician, Leonese and Valencian, but not the Caló/ Romani language (Council of Europe, 2015). There is therefore an interesting overall inconsistency: language is identified as an important element for the identity of the Roma in the Spanish FCNM report, but the Romani language is not recognized by the Spanish State neither in the ECML nor in national legislation. On the other hand, the Roma are the only minority included in the FCNM report, whereas officially recognized linguistic minorities that are included in the ECML and that hold co-official status with Castilian in certain Autonomous Communities (such as Basque, Catalan and Galician) are not even mentioned.

The introduction to the report is very clear in asserting that "This report describes the social policy measures implemented by the Ministry of Labour and Social Affairs in cooperation with the Roma community" (Spanish Government, 2000, p. 2). This, combined with the facts that the report was turned in with an almost two years delay and that the Spanish government refused to receive the delegation of the FCNM Advisory Committee during the first cycle, gives us a few important pieces of information on the Spanish approach. Firstly, the framework rests on a social policy approach, not a cultural identity one, even though the Roma are acknowledged as an ethnic minority. Secondly, the fact that the only minority acknowledged are the Spanish Roma can be seen in contrast with other minorities such as non-Spanish Roma or linguistic minorities such as the Catalan and the Basque. ${ }^{11}$

\section{Second cycle}

\section{Italy}

The second report submitted in 2004 by the Italian State was more detailed with respect to the Roma, including a special section titled The communities of Roma, Sinti and Travellers (Italian Government, 2004, pp. 20-28). Other than in the section title, however, the label that keeps being used in reference to Roma citizens is that of zingari, which is telling of the idiosyncrasies of the adopted approach. On the one hand, the Italian government defended in the report the position of not including the Roma in the scope of law 482/1999 on linguistic minorities; on the other hand it stated that the Roma were indeed an ethnic and cultural minority. 
"The very existence of this legislation [specific regional provisions] is important in itself since it is a form of recognition of the fact that Gypsies are an ethnic minority with a language and a culture of their own. In all above-mentioned provisions, nomadism is regarded as a basic element of the Gypsy culture: therefore, the right to nomadism, and consequently to stays, is openly stated."

(Italian Government, 2004, p. 25).

Apart from the report's endorsement of the regional laws (and therefore of the encampment system that the CoE had labelled as segregationist in the previous cycle), the attention to the Roma minority is, in the second Italian report, "put not only in consideration of the current situation, but also in view of the forthcoming enlargement of the European Union, since our country will number among those likely to be most considerably affected by the movements of Roma and Sinti within the newly defined European territory."12 (Italian Government, 2004, p. 25)

The Roma minority thus remains in the early 2000s, in the view of Italy's FCNM report and comments, a "problem" that is framed in terms of cultural distance (constructed on an alleged intrinsic nomadism of the Roma) from the majority society. At the same time, by addressing the mobility of citizens from new EU member states as a major concern, a superficial conflation is drawn between Italian Sinti, Roma who had fled Yugoslavia as asylum seekers, and European citizens of Roma ethnicity.

\section{Spain}

The second FCNM report of the Spanish government does not fundamentally alter the definition it had given of the Roma as Spanish Roma, even though it revised its Roma population from 600.000-650.000 to 650.000-700.000 (Spanish Government Ministry of Work and Social Affairs, 2006, p. 2). The second report, which was drafted during the socialist Zapatero government (while the first cycle had been under the conservative Partido Popular government led by Aznar), does however attest a stronger impulse in terms of both political and financial resources invested in the promotion of Roma inclusion. ${ }^{13}$

It is also noteworthy that, during this second FCNM cycle, a visit to Spain of representatives of the Advisory Committee was made possible, albeit with a closed agenda.

\section{Third cycle}

\section{Italy}

The third Italian report was submitted in 2009, not long after Silvio Berlusconi's Forza Italia had won the elections. One of the first moves of the neo-elected government was to declare a "Nomad State of emergency" which gave the Prefects of Rome, of Naples and of Milan special powers to deal with the so-called "emergency" through a legislative measure envisioned to face natural disasters $^{14}$ (emergency decree of 21 May 2008).

The Italian FCNM report however included no reasoning, justification nor acknowledgement of such measures, except for a brief mention at page 27 , in which the measures were framed as a necessary response to a "situation of social-environmental decay" that was taken "in order to fulfil the need for more security in favour of the inhabitants of the above settlements".

Based on such "decay", Roma families were evicted from "non-authorized" camps - either without alternative housing being provided, or the alternative being the relocation in "authorized" camps, highly securitized and imposing restricted mobility on its dwellers. These measures were justified by the "extremely complicated nature of the issue", as was the continued exclusion of the Roma minority from being recognized as a linguistic minority under Law No. 482/99 (Italian Government 2009, 24). 
The comments of the Italian government to the Advisory Committee's third opinion, which expressed alarm for the rise of xenophobia and anti-Gypsysm in Italy, did not envision any measure to tackle hate speech, but instead included a section titled The Status of Roma and Sinti in which the stress was put on the diversity of legal profiles (Italian citizens, EU citizens, third country nationals and stateless persons). The main argument put forward by the Italian government in this context was that the shortcomings in minority recognition and protection depended on the lack of a specific legal framework for Roma, which in turn hinged on the exceptionality and complexity attributed to the case of the Roma minority. Meanwhile, the reports kept referring to the Roma as "foreign nationals". 15

\section{Spain}

The third Spanish FCNM report presented the ongoing activities and plans in place, largely drawing from its previous report. A particular note of interest is the creation in May 2007 of the Roma Cultural Institute Foundation, which had been announced in the previous report: with the slogan España también es gitana [Spain is also Roma] (Spanish Government, 2010, pp. 22-23), it gave an important signal, even if largely symbolic - since the economic crisis meant that in these years not many resources went to cultural or social organizations. To claim Roma's identity as part of Spanish identity meant taking a step towards the inclusion of what were seen as elements of Roma culture (such as flamenco) into the mainstream. The third FNMN cycle was, however, also the document in which the first distinctions between Spanish and non-Spanish Roma started to emerge. The Advisory Committee noted with satisfaction that "no distinction is made" in the application of programmes between Spanish and non-Spanish Roma (Adivisory Committee on the FCNM of the Council of Europe, 2012, pp. 10, 35), but it also expressed concern at the fact that foreign Roma were particularly affected by prejudices and racism (p.19). In its 2013 resolution on the third Spanish cycle, the Council of Europe noted increased racism towards Roma (particularly foreign), migrants and an "anti-mosque" attitude, and suggested a thorough assessment of the economic crisis' impact on Roma in order to avoid further discrimination. ${ }^{16}$

\section{Fourth cycle}

\section{Italy}

The years between the submission of the third and fourth Italian reports saw a quick shift in governments over few years: a technocratic government led by Mario Monti between 2011 and 2013, followed by a government led by the Partito Democratico, with Enrico Letta as Prime Minister until February 2014, then replaced by Matteo Renzi until December 2016, who was in turn replaced by Paolo Gentiloni. These years also witnessed the development of a National Roma Integration Strategy, at the request of the European Commission in 2011 following the Communication on a EU Framework for National Roma Integration Strategies up to $2020 .{ }^{17}$ It is therefore not surprising that Italy's 2014 fourth FCNM report borrowed heavily from its recently submitted NRIS, claiming a strong break from previous policies and announcing renewed efforts in the integration of Roma, Sinti and Caminanti. The report however still retained many of the ambiguities in identifying the group as an "exceptional case" rather than a national minority. ${ }^{18}$

Despite the approval of the National Roma Integration Strategy, the continuation of an approach based on securitization can be found at pages 17-18 of the report, where the interventions financed by the PON Sicurezza (National Operational Programme "Security") for the period 2007-2013 are described as "very important". The Report also states that "the peculiar nature of the problems of social minorities involving marginalization and distress, such as those often associated with the 
condition of being an immigrant, a second generation immigrant, a stateless person, a foreign nomad or a nomad with Italian citizenship have made it necessary to alert the Juvenile Justice Services system to ensure a cultural mediation service (Italian Government 2014, p.17)."

The Advisory's Committee opinion praised the creation of an Anti-Discrimination Office (UNAR) which was appointed as the National Contact Point for the Italian NRIS, but it also noted that it lacked independence (since it is appointed by, and depends upon, the Council of Ministers). The Advisory Committee also condemned the continued use of the term "nomads" by public bodies, and the Council of Europe's resolution called for urgent steps to develop and implement a specific legislative framework for the protection of the Roma and for a review of UNAR in order to make it more independent and relevant.

\section{Spain}

Spain's government (led by the Partido Popular with Mariano Rajoy as Prime Minister since 2011) included information regarding the newly adopted NRIS in its fourth FCNM report, as Italy did. In this case the strategy was however seen not as a rupture with past policies but rather as their continuation - following the Roma Development Action Plan 2010-2012, and the framework for a Functional Plan on the Social Inclusion of Roma People 2014-2016.

The approach taken by such policies is consistent with the previous cycles: based on "universal measures - targeting disadvantaged segments of the population, which may have positive repercussions for the Roma population" and complemented with "specific measures for the Roma population targeted towards specific issues, subsidies, etc." (Spanish Government Ministry of Health Social Services and Equality, 2014, p. 5).

In its opinion, and in the final 2016 resolution, the Council of Europe stressed the need to reduce Roma inequality and to ensure that the cuts in welfare provision adopted following the economic crisis did not disproportionally affect Roma and other vulnerable groups.

\section{EMERGING CATEGORIES OF OTHERING FROM ROMA CLASSIFIERS}

As can be seen in Table 2, the definitions employed by the two governments in identifying "who the Roma are" over the four cycles of the FCNM are consistently divergent in Italy and Spain, outlining an understanding of what kind of minority the Roma constitute that rests on fundamentally different assumptions. One the one hand, Spain tends to focus in its identifications on socioeconomic aspects, while Italy frames the Roma residing in its territory mainly in terms of cultural difference. However, the differences go beyond the economic-cultural dichotomy, and two additional aspects that emerge as prominent in the reports are those of the migrant or foreign status, and of the "complexity" or "exceptionality" character attributed to the Roma minority. In the following paragraphs I attempt to organize and elaborate briefly on these four categories of "otherness" as constructed by the labelling of Roma minorities in Italy and Spain: the economic dimension, the cultural dimension, the foreign dimension and the exceptionality dimension. Table 2 represents how the Roma are constructed as a minority in Italy and Spain's FCNM reports and documents.

\section{The poor/ vulnerable as other}

The representation of the Roma that dominates the Spanish State reports for the Framework Convention on the Protection of National Minorities is that of an economically and socially vulnerable group. The wording employed tends to avoid the use of the term "minority", relying instead on 
TABLE 2

CHARACTERIZATION OF THE ROMA IN THE FCNM REPORTS PRESENTED TO THE COUNCIL OF EUROPE BY ITALY AND SPAIN

\begin{tabular}{|c|c|c|c|c|}
\hline & Culturally different & $\begin{array}{l}\text { Socio-economically } \\
\text { disadvantaged }\end{array}$ & Foreign/ migrant & $\begin{array}{l}\text { Exception/ } \\
\text { peculiarity }\end{array}$ \\
\hline $1^{\text {st }}$ cycle IT & $\begin{array}{l}\text { Should be more "incorpo- } \\
\text { rated" linguistically and } \\
\text { culturally in Italy }\end{array}$ & & & $\begin{array}{l}\text { Minority with no con- } \\
\text { nection to any par- } \\
\text { ticular territory }\end{array}$ \\
\hline $1^{\text {st }}$ cycle ES & & $\begin{array}{l}\text { The most unpopular of } \\
\text { the minority groups; } \\
\text { social policy mea- } \\
\text { sures implemented } \\
\text { by the Ministry of } \\
\text { Labour and Social } \\
\text { Affairs }\end{array}$ & & \\
\hline 2nd cycle IT & $\begin{array}{l}\text { Nomadism is regarded as } \\
\text { a basic element of the } \\
\text { Gypsy culture's "inborn" } \\
\text { tendency to resist } \\
\text { schooling. Cultural medi- } \\
\text { ators as the main policy }\end{array}$ & & $\begin{array}{l}\text { Worry of Roma } \\
\text { migration with } \\
\text { the forthcoming } \\
\text { enlargement of } \\
\text { the European } \\
\text { Union }\end{array}$ & \\
\hline 2nd cycle ES & & $\begin{array}{l}\text { Spanish legislation } \\
\text { and policy measures } \\
\text { of relevance to Roma } \\
\text { are mostly designed } \\
\text { for persons belonging } \\
\text { to economically and } \\
\text { socially vulnerable } \\
\text { groups rather than } \\
\text { specifically for Roma }\end{array}$ & & \\
\hline 3rd cycle IT & & & $\begin{array}{l}\text { EU citizens of } \\
\text { Roma ethnicity, } \\
\text { third country } \\
\text { nationals of } \\
\text { Roma ethnicity, } \\
\text { stateless }\end{array}$ & $\begin{array}{l}\text { Extremely compli- } \\
\text { cated nature of the } \\
\text { issue; need for } \\
\text { security and emer- } \\
\text { gency measures }\end{array}$ \\
\hline 3rd cycle ES & $\begin{array}{l}\text { "Spain is also Roma" (cre- } \\
\text { ation of the Consejo } \\
\text { Estatal del Pueblo } \\
\text { Gitano and of the Insti- } \\
\text { tuto de Cultura Gitana) }\end{array}$ & & & \\
\hline 4th cycle IT & Nomadism & & $\begin{array}{l}\text { "Illegal" and for- } \\
\text { eign nomads }\end{array}$ & $\begin{array}{l}\text { Peculiar nature of } \\
\text { the problems of } \\
\text { nomads }\end{array}$ \\
\hline 4th cycle ES & & $\begin{array}{l}\text { Universal measures- } \\
\text { targeting disadvan- } \\
\text { taged segments of } \\
\text { the population, which } \\
\text { may have positive } \\
\text { repercussions for the } \\
\text { Roma population; } \\
\text { 'peniaphobia' }\end{array}$ & & \\
\hline
\end{tabular}


identifications that target "disadvantaged segments of the population" or promote "specific measures for the Roma population targeted towards specific measures, subsidies etc." (Spanish Government Ministry of Health Social Services and Equality, 2014, p. 4).

On the one hand, this has the positive effect of explicitly including the Roma in Spain in welfare measures and anti-poverty schemes. On the other hand, however, the framing of Roma inclusion as a predominantly socio-economic matter has left little space for claims of recognition and for addressing cultural injustices. To date, with rare exceptions, the Roma are not mentioned in Spanish history textbooks, and the Caló language, which has never received any kind of institutional support, has a very reduced number of speakers as a result.

It has been argued that, in general, there is a trade-off between economic performance and multiculturalism (Chauvin \& Garcés-Mascareñas, 2014; Kymlicka, 2015). While impoverished, marginal groups can be seen as "deserving" because of their vulnerability, yet because of this the State can also concede less in terms of cultural recognition: "[i]n fact, individuals perceived as economically utile can 'buy' their cultural freedom, whereas groups from the South received by the cities are framed along their potential vulnerability. It is precisely this vulnerability that makes them deserving, but that also means that the assimilationist injunction is stronger" (Desille, 2018, 16). In this sense, it seems that Spain's approach towards its Roma population adheres to such a concept of deservingness.

\section{The culturally different as other}

On the other side of the spectrum, Roma's "cultural difference" from the majority population, especially framed in terms of nomadism, is very much present in Italy's reports and comments. This is not to say that Spain completely disregards the topic of Roma identity in its documents: for instance, the third Spanish FCNM report puts emphasis on the creation of a Roma Cultural Institute and on the fact that Romani culture is a core element of Spanish identity. The main difference in the narratives of the two countries is, rather, that while in Spain the cultural difference of the Roma from the non-Roma is seen as a product of historical persecution and segregation, in Italy it is portrayed as an inescapable and intrinsic ethnic trait - tied to customs and values that differ from, and are to some extent incompatible with, "Italian" ones.

The effect is specular. In Spain, Roma culture is seen, at least to some extent, as a consequence of marginalization, as is also reflected in some of the most recent regional policies. For instance, the 2015 Roma Integration Plan of La Rioja reads: "The cultural or ethnic identity [of the Roma] is to be understood in the first place by their past of having been a historically marginalized population" (Gobierno de La Rioja, 2015). Conversely, in Italy Roma culture is by and large constructed as itself the cause of marginalization and exclusion from 'normal' employment and lifestyle: the comments of the Italian government in the second cycle include statements such as "although schools are quite willing to receive nomads, they actually display a low inclination for integration" (Italian Government, 2005, p. 11).

\section{The migrant as other}

One frame that emerges as an important one in the ways in which the Roma are represented is that of migration. In the case of Italy, the second State report to the FCNM explicitly states the preoccupation with the forthcoming enlargement of the European Union, and the following report attempts to situate the Roma legally, dividing them according to their nationality. At the same time, the connotation of "nomads" being attributed to all Roma regardless of their legal status caters to the idea of an "internal outsider" which has more in common with migrants as "illegitimate entities" than with Italian nationals (Ibrahim \& Howarth, 2017). 
In Spain, the migrant frame is mostly present by omission: while the latest FCNM report acknowledges that there is a non-Spanish Roma population that might fall under the same policies as the Spanish Roma, the wording assumes that the integration plans are directed solely at Spanish Roma. The choice to "leave out" migrant Roma from the FCNM was to some extent a product of local and Spanish national Roma associations and movements' concern that stereotypes and racialized perceptions of the newcomers might be 'transferred' from the migrant groups to Spanish Roma (Magazzini \& Piemontese, 2016).

\section{The exception/complex issue as other}

While one of the core principles of the European guidelines for Roma inclusion is that of adopting an "explicit but not exclusive" approach, the attempts of both countries to exclude Roma migrants from national welfare provision have produced policies which address Roma in a rather "exclusive but non explicit" way.

In the case of Italy, the justification for its exclusion of the Roma minority from official recognition as a national minority is presented in terms of their 'exceptionality' or 'complexity'. Such frame serves as an argument to treat Roma (both national and non-nationals) as a population in need of an ad hoc (and often emergency-based) approach.

In the case of Spain, the situation is antithetical, in the sense that Roma are framed as citizens whose only peculiarity is to belong to a disadvantaged group which needs to "catch up" with the rest. Roma migrants are formally included as beneficiaries of Roma integration policies. Yet their inclusion in integration schemes is dependent on the beneficiaries being assessed according to 'objective' (which is to say, national) criteria, which non Spanish Roma tend to fail - because of either language or residential requirements (Vrăbiescu \& Kalir, 2017).

\section{CONCLUSION}

The starting point of this article was that the policies adopted in Europe over the past decades on the protection and promotion of minorities - be they national or migrant - are actually more concerned with reassuring national majorities than with protecting minority rights.

The Roma minority, which has catalysed so much political, economic and media attention in recent years, is a good litmus test to understand why minority-targeted measures develop in specific ways depending on the national context.

In Spain, the recognition of Roma as a minority that belongs to the Spanish national identity, even though it is socially and economically marginalized, is so far seen as fairly unproblematic. Compared to making concession to other minorities - such as the Basque and the Catalans, which are perceived as more politically problematic and polarizing - the promotion of Roma inclusion policies is presented as relatively apolitical. If anything, it allows the central government, irrespective of its political colour, to showcase at the international level how favourable Spain is towards its minorities. The main representation of the Roma as it is framed in the Spanish FCNM reports is therefore that of a socio-economic vulnerable group which is however deeply embedded in the Spanish nation. What falls outside this definition are non-Spanish Roma of recent immigration, who tend to fall through the cracks of inclusion policies.

In Italy, the picture is reversed: the accommodation of minority linguistic groups is generally seen as relatively unproblematic, and the power relations between the special autonomic regions and the central government is nowadays not a matter of serious debate. The Roma, instead - who are too scattered, fractioned, and disenfranchised to offer a different image of themselves to the majoritarian society - have historically functioned, and continue to function, as a scapegoat for 
anything from an inefficient welfare state to perceptions of rising criminality, especially in times of elections.

On the whole, what emerges from an analysis of the legal framing of the Roma in the two countries is that there are different ways of 'othering' minorities. In the case of the Roma as portrayed in the FCNM, the most relevant frames that emerge are the socio-economic (the poor/ vulnerable as "other"), the cultural (the culturally different as "other"), the legal status (the migrant as "other") and the deviant (the exception as "other").

In broader terms, the argument that this example supports is that the labelling of a minority as a"vulnerable" one, a "national" one, a "migrant" one or a "sui generis" one has little to do with objective analytical categories and more to do with power dynamics. Much of the difficulty of upholding the rights of racialized minorities comes from the fact that the framing of what kind of minority such a group constitutes depends more on political expediency than on the identity of the minority in question. If the Roma have emerged as a crucial case for testing the ways in which a group can be "socially and politically produced as a 'problem' within the context of the contemporary EU" (Yildız \& Genova, 2017), the representation that needs to be problematized is that of Europe itself. The problem, in short, is our (governments') lack of capacity or willingness to engage with underprivileged groups in ways that are inclusive, rather than othering.

The solution to integration and migration issues should therefore be addressed and worked upon not in the cultural, economic, or legal sphere, but first and foremost in the political realm. This is the great future challenge for Europe: in order to successfully tackle its current so-called migration and integration crisis it must acknowledge that the matter is political, and confront it accordingly.

\section{ACKNOWLEDGEMENTS}

The research leading to these results has received funding from the European Union's Seventh Framwork Programme (FP7/2007-2013) under grant agreement n. 316796.

\section{NOTES}

1. For an overview of the development of Europe-wide discourses on Roma since the collapse of Eastern European state socialism see (Baar, 2017; Kóczé, 2017; Magazzini, 2016).

2. In August 2015 Slovak Prime Minister Robert Fico affirmed: “After all, let's be honest, we aren't even capable of integrating our own Romani fellow citizens, of whom we have hundreds of thousands. How can we integrate people who are somewhere else completely when it comes to lifestyle and religion?" See https://theconversation.com/how-the-refugee-crisis-is-dealing-another-blow-to-europes-roma-74000.

In October 2016 the Council of Europe published a document outlining how the increased number of asylum-seekers and refugees arriving to Europe were affecting the situation of the Roma. See https://wcd.coe. int/com.instranet.InstraServlet?command=com.instranet.CmdBlobGet $\&$ InstranetImage=2947279\&SecMode= $1 \&$ DocId $=2385346 \&$ Usage $=2$

3. Roberto Maroni, an Italian politician who is currently the President of Lombardy, was one of the founders of the political party Lega Nord (Northern League). He held the office of Minister of the Interior under the first Berlusconi cabinet (1994-1995) and again after the 2008 electoral victory of the center-right coalition led by Berlusconi, when a "nomad emergency" was declared.

4. In 2009 and 2010 the French government repatriated thousands of Romanian and Bulgarian Roma as part of a campaign aimed at the eviction of Roma from alleged illegal camps. The evictions and expulsions of Romanian and Bulgarian Roma nationals by France during the summer of 2010 and the reaction by Viviane Reding, then Vice-President of the European Commission, are generally regarded as one of the triggers for putting Roma integration on the EU agenda. For more information, see Carrera, 2013; Doytcheva, 2015; Kóczé, 2017.

5. See http://www.coe.int/en/web/minorities/rules-of-procedure, point 34 and below. 
6. The composition of the Advisory Committee can be consulted here: http://www.coe.int/en/web/minorities/ current-composition.

7. Law 482/1999 provides protection on the basis of four main principles: ethnicity, language, history and presence in a specific territory (Palermo, 2004).

8. No specific source is cited about the estimated Roma population. At page 31 the report states that "The numbers of the latter groups are established on the basis of studies and publications; the figures in the following tables are therefore purely indicative."

9. The difference in life expectancy at birth between Roma and non Roma in Spain is of approximately 10 years (Fundamental Rights Agency \& UNPD, 2012).

10. This is the "highly heterogeneous, but a single minority" formula that will often later be adopted in EU documents. The attempt to not appear as essentializing the Roma yields to using Roma as an "umbrella term" which is inclusive yet ambiguous and open to interpretation.

11. Additionally, attention is made to avoid any reference to the concept of "national" in any way that could diverge from that of "Spanish".

12. On the construction of Roma as "nomads" in the Italian political and legislative discourse, see, among others Armillei (2014), Maestri (2016), Sigona (2005, 2011).

13. With Royal Decree No. 891/2005 of 22 July 2005, the Spanish government instituted the State Council for the Roma People as a consultative body attached to the Ministry of Labour and Social Affairs, and in September 2005 the Lower House of the Spanish Parliament adopted a 'Non-binding proposal on the recognition of the rights of Roma'. Also in 2005, the Congress of Deputies passed a bill calling on the government to promote the culture, history, identity and language of the Roma people, while the Ministry of Culture earmarked the creation of an Institute of Roma Culture as one of its priority objectives.

14. For an overview of the emergency decree and its follow-up, see European Roma Rights Centre, 2010; Presidente del Consiglio dei Ministri, 2008, 2010; Sigona \& Monasta, 2006.

15. For instance, the report states: "[r]egularly staying foreign Roma benefit from the protective provisions envisaged in favour of immigrants by legislation in force, which is based on the principle of integration of foreign citizens in the social context." (Italian Government, 2009, p. 20).

16. For an overview on the differences in treatment and conceptualization between Spanish and non-Spanish Roma in Spain, see Magazzini \& Piemontese, 2016; Vrăbiescu \& Kalir, 2017.

17. $\operatorname{COM(2011)~} 173$ final, available at http://eur-lex.europa.eu/LexUriServ/LexUriServ.do?uri=COM:2011: 0173:FIN:EN:PDF

18. "No specific piece of legislation of our legal system recognizes and protects the Roma communities living in Italy as linguistic minorities as they lack a stable connection with the territory, as it is well known." (Italian Government, 2014, p. 10).

\section{REFERENCES}

Adivisory Committee on the FCNM of the Council of Europe

2012 Opinion of the Advisory Committee on the third Spanish Report on the FCNM, March, 1-51.

Aiginger, K., and T. Leoni

2009 Typologies of Social Models in Europe. Institute of Economic Research WIFO.

Arango, J., C. Finotelli, C. Sabino, S. Strozza, and A. Triandafyllidou

2009 The making of an immigration model: Inflows, impacts and policies in Southern Europe. IDEA Working Papers.

Armillei, R.

2014 "Neither Included, Nor Excluded : The Paradox of Government Approaches Towards the Romanies in Italy", Citizenship and Globalisation Research Paper Series, 5(3): 1-22.

Baar, H.Van.

2017 "Contained mobility and the racialization of poverty in Europe: the Roma at the development security nexus", Social Identities, 1-17. https://doi.org/10.1080/13504630.2017.1335826.

Bacchi, C.L.

2009 Introducing a "what"s the problem represented to be?' approach to policy analysis. in Analysing Policy: What's the Problem Represented to Be?, Pearson: 1-53. 
Carrera, S.

2013 "Shifting Responsibilities for EU Roma Citizens The 2010 French affair on Roma evictions and", CEPS Paper in Liberty and Security in Europe, 55: 1-28.

Chauvin, S., and B. Garcés-Mascareñas

2014 "Becoming Less Illegal: Deservingness Frames and Undocumented Migrant Incorporation", Sociology Compass, 8(4): 422-432. https://doi.org/10.1111/soc4.12145.

Ciaian, P., and D. Kancs

2016 Causes of the Social and Economic Marginalisation. The Role of Social Mobility Barriers for Roma. JRC Technical Reports.

Council of Europe

1992 European Charter for Regional or Minority Languages, accessible at https://www.coe.int/en/web/ conventions/full-list/-/conventions/rms/0900001680695175.

2016a Cultural Policies and Trends in Europe. Italy, General Legislation. Council of Europe/ ERICarts, Compendium of Cultural Policies and Trends in Europe, 17th Edition. https://doi.org/2222-7334

2016b Framework Convention for the Protection of National Minorities Factsheet. Retrieved from http:// www.coe.int/en/web/minorities/fcnm-factsheet

2016c The situation of Roma and Travellers in the context of rising extremism, xenophobia and the refugee crisis in Europe (Vol. 31).

2016d Thematic Action Plan on the Inclusion of Roma and Travellers (2016-2019).

Desille, A.

2018 Exclusion within Integration, in S. Hinger and R. Schweitzer (Eds), Regimes of Dis-Integration, IMISCOE Book Series, Springer.

Doytcheva, M.

2015 "Roms et Tsiganes en Europe méditerranéenne: l'actualité d'une question", Confluences Méditerranée, 93(2): 9-26.

European Commission

2015 A European Agenda on Migration. COM(2015) 240 final, Brussels: European Commission.

2016 Action Plan on the Integration of Third Country Nationals. COM 377 final. Brussels.

European Roma Rights Centre

2010 Submisson of the European Roma Rights Centre, OsservAzione and Amalipé Romanò concerning Italy for consideration under the universal periodic review by the United Nations Human Rights Council at its 7 th session.

Fundamental Rights Agency, \& UNPD

2012 The situation of Roma in 11 EU Member States. Survey results at a glance. (Fundamental Rights Agency, Ed.). Luxembourg. https://doi.org/10.2811/76056

Gobierno de La Rioja.

2015 I Plan integral de la población gitana de La Rioja 2015-2018. Logroño.

Ibrahim, Y., and A. Howarth

2017 "Communicating the 'migrant' other as risk: space, EU and expanding borders", Journal of Risk Research, 1-22: https://doi.org/10.1080/13669877.2017.1313765.

Italian Government

1999a First Report submitted by Italy on the FCNM.

1999b Law No. 482 (1999) Norme in materia di tutela delle minoranze linguistiche storiche. Gazzetta Ufficiale, 297(Article 1.1), 2-4.

2002 Government of Italy Comments on the first opinion of the Advisory Committee on the FCNM.

2004 Second Report submitted by Italy on the FCNM.

2005 Government of Italy Comments on the second opinion of the Advisory Committee on the FCNM.

2009 Third Report submitted by Italy on the FCNM.

2014 Fourth Report submitted by Italy on the FCNM.

Kóczé, A.

2017 "Race, migration and neoliberalism: distorted notions of Romani migration in European public discourses", Social Identities. http://doi.org/http://dx.doi.org/10.1080/13504630.2017.1335827

Kostka, J.

2015 Implementation of Roma Inclusion Policies: Why Defining the Problem Matters. Social Inclusion, 3 (5): 78 . https://doi.org/10.17645/si.v3i5.231 
Kymlicka, W.

2015 "Solidarity in Diverse Societies: Beyond Neoliberal Multiculturalism and Welfare Chauvinism", Comparative Migration Studies, 3(17), https://doi.org/10.1186/s40878-015-0017-4.

Maestri, G.

2016 "Are they nomads, travellers or Roma? An analysis of the multiple effects of naming assemblages", Area, https://doi.org/10.1111/area.12273.

Magazzini, T.

2016 "Cultural Institutions As a Combat Sport. Reflections on the European Roma Institute", The Age of Human Rights Journal, 7: 50-76.

Magazzini, T., and S. Piemontese

2016 "“"Roma" migration in the EU: the case of Spain between "new" and "old" minorities", Migration Letters, 13(2): 228-241.

McGarry, A.

2017 Romaphobia. The last acceptable form of racism. Zed Books, Chicago.

McMahon, S.

2015 Immigration and Citizenship in an Enlarged European Union. The political dynamics of intra-EU mobility. Palgrave Macmillan.

Palermo, F.

2004 "Le minoranze linguistiche in Italia dopo la legge generale di tutela, Quo vadis Romania?" Zeitschrift für eine aktuelle Romanistik, vol. 23, pp.35-46.

Penalva-Verdú, C., and L. Raffini

2015 Monográfico. Los efectos sociales, políticos y económicos de la crisis en Italia y España. Obets, 10 (1), 272.

Presidente del Consiglio dei Ministri

2008 Decreto del Presidente del Consiglio dei ministri, 21 maggio 2008. Dichiarazione dello stato di emergenza in relazione agli insediamenti di comunità nomadi nel territorio delle regioni Campania, Lazio e Lombardia

2010 Decreto del Presidente del Consiglio dei ministri, 7 dicembre 2010.

Rossi, M.

2016 (February 27). La trappola dell'etnicità: gabbia e risorsa. Il Manifesto. Rome, Italy. Retrieved from http://ilmanifesto.info/la-trappola-delletnicita-gabbia-e-risorsa/

Ruiz Vieytez, E. J.

2013 “A New Political Status for the Basque Country?", Journal on Ethnopolitics and Minority Issues in Europe12(2), 79-105.

Sardelić, J.

2016 "The position and agency of the "irregularized": Romani migrants as European semi-citizens", Politics, 263395716668537: https://doi.org/10.1177/0263395716668537.

Sardelić, J., and A. McGarry

2017 (March 20). How the refugee crisis is dealing another blow to Europe's Roma. The Conversation. https://theconversation.com/how-the-refugee-crisis-is-dealing-another-blow-to-europes-roma-74000 (accessed 22 February 2018)

Sigona, $\mathrm{N}$.

2005 "Locating 'The Gypsy Problem'. The Roma in Italy: Stereotyping, Labelling and 'Nomad Camps", Journal of Ethnic and Migration Studies, 31(4): 741-757. https://doi.org/10.1080/ 13691830500109969.

2011 "The governance of Romani people in Italy : discourse, policy and practice", Journal of Modern Italian Studies, 16(5): https://doi.org/10.1080/1354571X.2011.622468.

Sigona, N., and L. Monasta

2006 "Quasi-citizenship or Imperfect Citizenship. Research into patterns of racial discrimination against Roma and Sinti in Italy", European Roma Rights Centre, OsservAzio(September): 1-35.

Sigona, N., and N. Treheran (Eds).

2009 Romani politics in contemporary Europe: poverty, ethnic mobilisation and the new liberal order. Palgarve Macmillan. 
Spanish Government

2000 First Report submitted by Spain on the FCNM (Vol. 5).

2010 Third Report submitted by Spain on the FCNM.

Spanish Government Ministry of Health Social Services and Equality.

2014 Fourth Report submitted by Spain on the FCNM.

Spanish Government Ministry of Work and Social Affairs

2006 Second Report submitted by Spain on the FCNM.

Surdu, M.

2016 Those Who Count. Expert Practices of Roma Classification. Central European University Press, Budapest.

Tavani, C.

2012 Collective Rights and the Cultural Identity of the Roma. A case study of Italy. Martinus Nijhoff Publishers, Leiden/ Boston.

The Council of Europe

2016 Advisory Committee on the Framework Convention for the Protection of National Minorities ACFC/56DOC(2016)001. The Framework Convention: a key tool to managing diversity through minority rights.

Vermeersch, P.

2013 "The European Union and the Roma: an analysis of recent institutional and policy developments", European Yearbook of Minority Issues, 9: 341-358.

Vrăbiescu, I., and B. Kalir

2017 "Care-full failure: how auxiliary assistance to poor Roma migrant women in Spain compounds marginalization", Social Identities: https://doi.org/10.1080/13504630.2017.1335833.

Willems, W.

1997 In Search of the True Gyspsy: From Enlightment to Final Solution, Frank Cass, London; Portland, OR.

Yıldız, C., and N. de Genova

2017 "Un / Free mobility Roma migrants in the European Union", Social Identities, 23(4): 1-17. https://doi.org/10.1080/13504630.2017.1335819. 